\title{
Fra opiumsetere til morfinister - to historier fra 1800-tallet
}

\author{
Overgangen fra bruk av opiumsdråper til opioider som morfin og injeksjonssprøyter fra midten av 1800-tallet \\ er godt dokumentert, både fra Tyskland, England og USA. I Norge er dette lite dokumentert, men to kasuistik- \\ ker publisert i denne perioden er illustrerende for overgangen også her i landet.
}

Siden oldtiden har opium vært et hyppig brukt legemiddel, især mot smerter. Det ble også anvendt som sedativ, ved visse magetarm-lidelser og ikke minst ved hoste. Farene ved opiumsforgiftning ble tidlig kjent, likeledes kjente antikkens leger til opiumets vanedannende egenskaper (1).

Opium ble brukt i Europa fra 1500-tallet nærmest som en panasé og ble lovprist av legene for sin bruksbredde og effekt. Den store engelske kliniker Thomas Sydenham (1629-89) skrev: «Among the remedies which it has pleased the almighty God to give to man to relieve his sufferings, none is so efficacious as opium» (2). I vår kulturkrets ble opium den gang i hovedsak inntatt som dråper, for eksempel som laudanum, en $10 \%$ opiumsoppløsning i alkohol.

Allerede mot slutten av 1700-tallet ble det advart mot misbruk. Legen Samuel Crumpe (1766-96) skrev at opium skapte avhengighet $o g$ at brukere som var uten opium bare for en enkelt dag «became languid, dejected and uneasy» (3). Dette ble bekreftet av blant andre diktere og litterater som Thomas de Quincey (1785-1859) og Samuel Coleridge (1772-1834) (4). Det var for øvrig de Quincey som gjennom sin bok fra 1821 Confessions of an English opiumeater gjorde begrepet «opiumseter» kjent.

\section{En opiumseter på Hamar i 1855}

10. august 1855 ble en hotellgjest på Hamar funnet død i sin seng (5). Dagen etter ble det avholdt politiforhør.

Hotellverten, som var hovedvitne, forklarte at gjesten som var ankommet 12 dager tidligere. Han hadde klaget over smerter i brystet, men også over «Rheumatisme i den ene Side og Armen». Gjesten ble anbefalt å søke legehjelp, men det kom ikke på tale. Imidlertid hentet han selv en «Iglekone, som paasatte ham en Deel Igler. Dette skeede Dagen før hans Død». Avdøde kunne av og til virke «lidt beskjænket», derfor la hotellverten ikke så stor vekt på at han fortalte at han av og til kunne sove i flere dager i trekk fordi han hadde «stærk Sovesyge».

Deretter fulgte vitneforklaringen til farmasøyten ved apoteket på Hamar. Han fortalte at avdøde hadde fått utlevert laudanum 3-4 ganger. Ifølge farmasøyten ble det i alt utlevert 3-4 drakmer, tilsvarende ca. 11-12 gram opium. Det ble også angitt at hver gang avdøde besøkte apoteket, «forekom han at være noget beruset». De øvrige vitnene brakte intet nytt i saken.

\section{Rettsmedisinsk unders $\varnothing$ kelse}

Amtslege Albert Blehr (1805-72) ble så beordret til å foreta en «Besigtigelsesforretning». Rapporten forelå to dager senere: «Deponenternes (vitnenes) Forklaringer under Forhøret vakte stærk Mistanke om at Afdøde har været en saakaldt Opiumsæder. En som ved hyppig Nydelse af Opiater i større Doser hensættes derved i en eiendommelig Beruselsestilstand. Om han, ved at gjøre dette $\mathrm{i}$ en Tid, derved har nedbrudt sin Helbred, eller om han nu, i Hensigt at tage sig selv af Dage, har paa en Gang indtaget en større Portion Opiumsdraber som haver havt Døden til Følge, lader sig af de anførte Oplysninger ikke sikkert afgjøre, ligesaalidt som dette vil kunde opnaaes ved Deduction med fastsat Undersøgelse paa Opiumforgiftning» (5).

Ut fra dagens viten er det vanskelig å trekke noen sikker konklusjon ut fra de opplysninger som forelå. Det er likevel lett å være enig med amtsfysikus Blehr da han tilskrev dødsfallet langvarig opiumsbruk og «nedbrudt Helbred».

\section{Utviklingen på 1800-tallet}

Opiumsforbruket økte utover i århundret, sannsynligvis som følge av at stoffet var lett tilgjengelig (i England var opium i fritt salg over disk til 1868) og fordi legene hadde en tendens til overforskrivning slik at antallet avhengige økte (3). Fortsatt var det blant legene en overbevisning at fordelene ved bruk på medisinske indikasjoner var viktigere enn ulempene.

Fra midten av 1800-tallet ble legene mer oppmerksomme på ulempene ved opoidbruk, og det kom til et merkbart tidsskifte. Det hadde blant annet sammenheng med

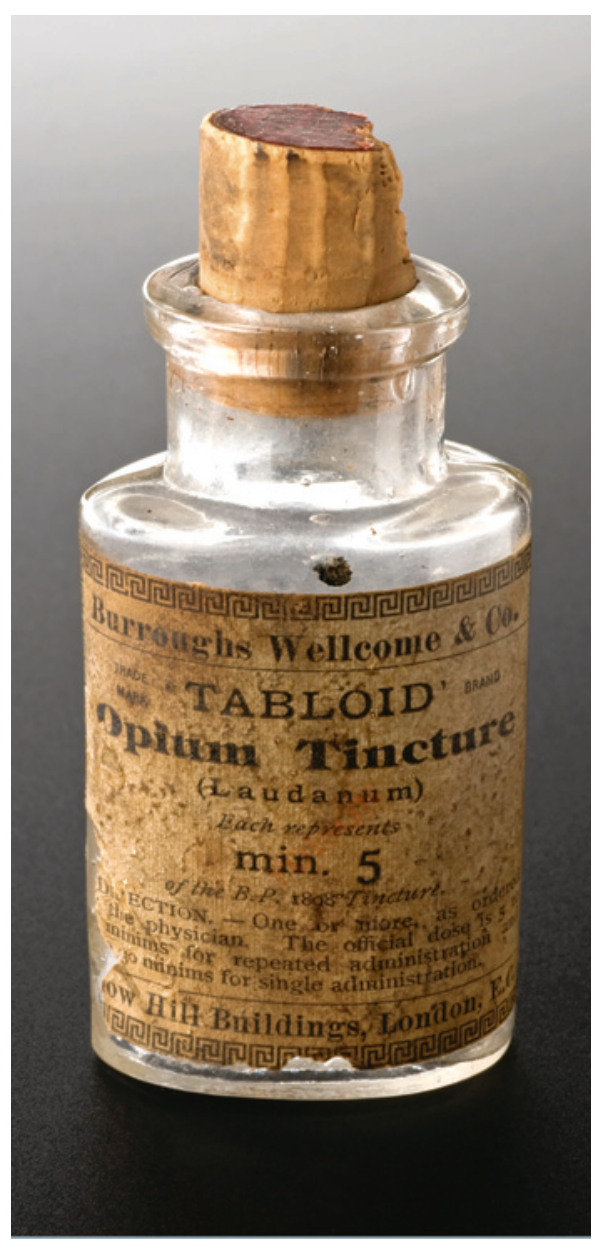

Opiumstinktur. Foto: Science Museum, London, Wellcome Images

de tekniske nyvinningene på denne tiden. I første rekke gjaldt det de renfremstilte opioider som daterte seg tilbake til 1805 da morfin ble isolert. I 1853 kom injeksjonssprøyten i bruk. Denne kombinasjonen innebar en raskere effekt av morfin, men også en økende risiko for tilvenning (6).

Markedsføringen tok også nye og mer aggressive veier. I 1870-80-årene ble opioider fortsatt solgt fritt i USA, og velkjente farmasøytiske fabrikker markedsførte sett bestående av injeksjonssprøyter og opioider. Stor skade gjorde også patentmedisinene, som ofte inneholdt liberale mengde opiumsderivater og fritt ble sendt som postordre (7). 
Fra 1860-70-årene ble det publisert stadig flere rapporter fra flere land om opiumsavhengighet. En av forfatterne var den tyske legen Eduard Levinstein (1831-82) som publiserte Die Morphiumsucht nach eigenen Beobachtungen i $1877(8,4)$. Her ble morfinavhengighet for første gang analysert og definert. Arbeidet ble publisert året etter i England og er også nevnt i nyere medisinhistorisk litteratur $(4,3)$. Levinstein klassifiserte for øvrig morfinisme som sykdom og fant likhetspunkter med dipsomani.

\section{«Morfinismus chronicus»}

Jeg har manuelt gjennomgått de norske medsinske tidsskriftene Eyr (fra 1826 til 1838), Ugeskrift for Medicin og Pharmacie (fra 1842 til 1845) og Norsk Magazin for Logevidenskaben (fra 1840 til 1899). Gjennomgangen viste at den sannsynlig første norske artikkelen om opioidavhengighet ble skrevet av daværende reservelege ved Rikshospitalet Andreas Backer (1830-1913) og publisert i 1873 (9).

Artikkelen, en kasuistikk, åpner med setningen: «Det er saavidt jeg ved, første Gang, at denne Sygdom nævnes i Indberetningerne fra Rigshospitalet» (9). Dette stemmer godt med at publikasjoner om medikamentavhengighet var sjeldne, men også med at amtsfysikus Blehr var tidlig ute i 1855 med sin beskrivelse av opiumseteren på Hamar.

Andreas Backers kasuistikk handlet om en ung, gift kvinne fra landet: «Hun er reist herind alene for at helbredes for sin sygelige Tilbøielighed til Brugen af Morfininjektioner» (9). Hun hadde vært nervøs og svak siden puberteten, «og led senere af Dysurie og Krampetilfælde af hysterisk Form». Hun led også av et smertesyndrom; «Ischiaslignende Neuralgi». Det siste året var hun i hovedsak behandlet med «subcutane Morfininjektioner, som hun benyttede efter eget Forgodtbefindende. Hun kunde ikke undvære dem og havde brugt indtil 12 Injektioner i Døgnet og i 1 Aar angivelig brugt for omtrent 70 Spd.». Dette tilsvarte omtrent to ganger årslønnen til en tjenestepike på landet. «Hun havde da stadig befundet sig i Morfinrus, og naar hun en enkelt Gang manglede Morfin, søgte hun at bedøve sig ved Nydelse til Overmaal af stærke Drikke». Etter en måneds innleggelse ble pasienten utskrevet fra Rikshospitalet, angivelig som helbredet. Behandlingen var kloralhydrat $2 \mathrm{mg}$ om aftenen.

Fra 1870-årene hadde Magazinet flere artikler om morfinisme. En av dem var et referat i 1876 ved Axel Lund (1842-1922) av en artikkel fra 1875 av den overnevnte Levinstein i Berlin om kronisk morfinisme (10). Dette indikerer at Magazinet var tidlig ute med informasjon til legene om et økende medisinsk problem.

\section{Avslutning}

Overgangen til et annet misbruksmønster av opioider gjaldt de fleste land $i$ vår kulturkrets, inkludert Norge. Det er indikasjoner på at det norske medisinske miljøet var oppdatert og etter forholdene vel orientert om denne utviklingen.

Opioidavhengighet ble definert som sykdom i denne perioden. Dette hadde sammenheng med at medisinens stilling i samfunnet var blitt sterkere som følge av de naturvitenskapelige fremskritt $i$ tiden. Medikaliseringen medførte at en dypere forståelse av de sosiale og kulturelle røtter til opiumsbruk ble skjult og ikke aktualisert før etter den annen verdenskrig, da stoffmisbruk antok andre og større dimensjoner (4).
Det er verdt å merke seg at etter hvert som opioidenes skadevirkninger ble erkjent og forståelsen for at medikamentavhengighet var iatrogent betinget økte, ble det etablert restriktiv lovgivning i de enkelte land, senere også internasjonalt.

\section{Hans Petter Schjønsby}

schoejn@online.no

Hans Petter Schjønsby (f. 1936) er pensjonert fylkeslege i Hedmark.

\section{Litteratur}

1. Scarborough J. The opium poppy in hellenistic and roman medicine. I: Porter $\mathrm{R}$, Teich $\mathrm{M}$, red. Drugs and narcotics in history. Cambridge: Cambridge University Press, 1995

2. Aggrawal A. Narcotic drugs. Kap. 2. The story of opium. New Dehli: National Book Trust, 1995

3. Porter R. The greatest benefit to mankind. A medical history of humanity from antiquity to the present. London: Fontana press, 1999.

4. Berridge V, Edwards G. Opium and the People. New Haven, CT: Yale University Press, 1987.

5. Statsarkivet i Hamar. Amtmannsarkivet, Hedemarkens amt. Brev fra leger etc. 1855. Boks 820.

6. Musto DF. Concept of addiction: the US experience. The Cambridge world history of human disease. Kap. III 7. Cambridge: Cambridge University Press, 1993.

7. Musto DF. Opium, cocaine and marijuana in American history. Sci Am 1991; 265: 40-7.

8. Musto DF. The American disease. Origins of narcotic control. Oxford: Oxford University Press, 1999

9. Becker A. Morfinismus chronicus. Indberetning fra Rigshospitalets medicinske Afdeling for Aare 1872. Norsk Magazin for Lægevidenskaben 1873 27: $401-22$

10. Lund A. Kronisk morfinisme. Uddrag og kortere Meddelelser. Norsk Magazin for Lægevidenskaben 1876 ; 30 : $466-8$.

Mottatt 28.2. 2014, første revisjon innsendt 10.6. 2014, godkjent 31.7. 2014. Redaktør: Are Brean. 